\title{
EFFECT OF ORAL L-TYROSINE TREATMENT DURING MID- LACTATION OF FRIESIAN DAIRY COWS ON MILK YIELD AND ITS REPRODUCTIVE PERFORMANCE
}

\author{
I.M. Abd El-Razek \\ Animal Production Department, Faculty of Agriculture, Kafrelsheikh University, Egypt.
}

(Received 24/11/2015, accepted 2/2/2016)

\section{SUMMARY}

\begin{abstract}
A total of 30 Friesian dairy cows aged 31-59 months with an average live body weight $502.6 \mathrm{~kg}$ were divided into three similar groups based upon age, live body weight and milk yield to evaluate the effect of oral L-tyrosine administration on milk yield and reproductive performance of Friesian dairy cows at day 121 or 140 post calving (during mid-lactation). Cows in the first group (G1) were fed concentrate feed mixture (CFM) and considered as a control group. While, those in the $2^{\text {nd }}(\mathrm{G} 2)$ and $3^{\text {rd }}(\mathrm{G} 3)$ groups were received an oral dose of $50 \mathrm{~g} / \mathrm{cow}$ L-tyrosine at day 121 and 140 of postpartum, respectively. Results revealed that L-tyrosine treatment significantly $(\mathrm{P}<0.05)$ increased the average daily milk production during the $2^{\text {nd }}$ four months of lactation in term of actual milk yield (AMY), 4\% fat corrected milk yield (FCMY), milk composition, and decreased the number somatic cell count (SCC) in milk compared to the that of the control one. L-tyrosine treatment was also improved reproductive performance and overcomes reproductive problems associated with ovarian activity such as incidence of estrus, interval from calving to the first estrus, postpartum first service, days open, number $o$.

f services per conception and finally improved conception rate. In conclusion: based upon the results obtained in this study, L-tyrosine could be used for treating cows during postpartum periods to improve cow's reproductive performance by overcoming their reproductive problems and enhancing milk production and its composition.
\end{abstract}

Keywords: Friesian cows, L-tyrosine, milk yield, progesterone, reproduction.

\section{INTRODUCTION}

Some authors suggested the use of some organic substances possessed to improve the productivity and reproductive efficiency of animals through enhancing the release of sex hormones (Abu El-Hamd and Sayah, 2015). One of these substances is L-tyrosine, which is a semi essential amino acid involved in the formation of catecholamine from adrenal gland and thyroxin from thyroid gland (Hammerl and Russe, 1987a). Tyrosine serves as a precursor for the synthesis of dopamine, norepinephrine, and epinephrine and is a specific brain neurotransmitter implicated in the control of GnRH and LH pulses and LH surge (Ramirez et al., 1984). The treatment by some amino acids, especially tyrosine led to improve significantly reproductive and productive performance (El-Amrawi, 2008).

These amino acids may partly mediate the effect of dietary protein on the metabolism of protein, lipids and glucose, fertility, growth and production performance; and health of animals (Kim et al., 2007). The amino acid tyrosine, a blood-borne metabolite, may be involved in stimulating GnRH release because availability of tyrosine influences synthesis of norepinephrine (Gibson and Wurtman, 1986 and Acworth et al., 1988), a neurotransmitter that stimulates GnRH release (Ramirez et al., 1984 and Terasawa et al., 1988). The relationship between tyrosine and reproduction has been reported by many authors. In dairy cows, the anestrous animals (no palpable ovarian structures or detected estrus by 60 to $150 \mathrm{~d}$ postpartum) had lesser concentrations of tyrosine in blood plasma than estrus-cycling controls (Hammerl, 1986). Also, it was noted that more than $85 \%$ of anestrous dairy cows expressed estrus within several days after tyrosine treatment and continued to have normal estrous cycles (Munsterer, 1987). Moreover, El-Amrawi, et al. (1992) postulated that a single oral dose (100 $\mathrm{mg} / \mathrm{kg} / \mathrm{LBW}$ ) of L-tyrosine could induce the puberty in delayed pubertal buffalo heifers. In addition, Gabr (2009) found that the double oral dose from L-tyrosine containing $100 \mathrm{mg} / \mathrm{kg}$ live body weight (LBW) at 15 day-interval induced early puberty of rabbit bucks. In cows, exogenous tyrosine increased 
LH pulse frequency in growth-restricted lambs (Hall et al., 1992), induced follicular growth, estrus, and ovulation in anovulatory dairy cows (Hammerl, 1986 and Munsterer, 1987) and improved expression of estrus (Hammerl and Russe, 1987b). Therefore, the aim of current work was to study the effect of oral single dose of L-tyrosine ( $50 \mathrm{~g} / \mathrm{cow})$ at day 121 or 140 post calving (mid-lactation) on milk yield, its composition and reproductive performance of Friesian dairy cows.

\section{MATERIALS AND METHODS}

The present study was carried out at Sakha Animal Production Research Station, belonging to the Animal Production Research Institute, Agricultural Research center, Ministry of Agriculture, during the period from July to November 2014.

\section{Animals:}

A total of 30 Friesian cows averaging $502.6 \pm 23 \mathrm{~kg}$ live body weight (LBW), ranging between 3159 months of age and 1-3 parities was used in this study. All cows were chosen at mid-lactation, 121 and 140 days post calving. At the beginning of the experimental period, the experimental cows were divided into three similar groups of 10 cows each according to their LBW, parity and milk production. Cows in the $1^{\text {st }}$ group were fed a basal diet without treatment and considered as a control group (G1), while cows in $2^{\text {nd }}(\mathrm{G} 2)$ and $3^{\text {rd }}(\mathrm{G} 3)$ groups were received an oral dose from L-tyrosine $(50 \mathrm{~g} / \mathrm{cow})$ on day 121 and 140 of postpartum period, respectively. All cows were free of any diseases with healthy appearance and housed in separated groups under semi-open sheds.

\section{Feeding system and management:}

Throughout the experimental period, cows in all groups were fed equal amounts of a diet containing concentrate feed mixture (CFM), rice straw (RS) and corn silage (CS) according to the recommendation of the NRC (2001) allowances for dairy cows based on live body weight and milk yield. The CFM was composed of $37.5 \%$ yellow corn, $20 \%$ soybean meal, $15 \%$ corn gluten, $22.5 \%$ wheat bran, $3 \%$ molasses, $0.5 \%$ and $1.5 \%$ common salt. Chemical analysis of representative monthly samples of foodstuffs was analyzed for CP, CF, EE, NFE and ash on DM basis according to the official methods of the A.O.A.C. (2000). Chemical composition of CFM, RS and corn silage as well as the calculated chemical composition of the basal diet used in feeding cows in all groups are shown in Table (1).

Table (1): Chemical analysis of different feed stuffs (on dry matter basis) used in feeding cows in all groups.

\begin{tabular}{lccc}
\hline \multirow{2}{*}{ Item } & \multicolumn{3}{c}{ Chemical composition $(\%)$} \\
\cline { 2 - 4 } & CFM & RS & Corn silage \\
\hline DM & 90.42 & 88.74 & 36.14 \\
OM & 89.54 & 82.83 & 92.4 \\
CP & 15.34 & 1.61 & 9.35 \\
CF & 11.46 & 37.36 & 17.15 \\
EE & 5.02 & 1.51 & 3.04 \\
NFE & 57.72 & 42.35 & 56.8 \\
Ash & 10.46 & 17.18 & 7.6 \\
\hline
\end{tabular}

\section{Experimental procedures:}

\section{Milk yield and composition:}

According to the managerial practices applied in the farm, cows were milked twice daily at 6:00 and 17:00 h by milking machine. Daily milk yield was individually recorded for morning and evening milkings for the $2^{\text {nd }}$ four months of lactation after treatment. Individual milk samples were monthly collected for determining milk composition using Milko-Scan (Model 133B) and somatic cell count using a Fossomatic 360 (Foss Electronic, Slangerupgade, Denmark). 


\section{Blood sampling:}

Blood samples were collected with anticoagulant (heparin) from the jugular vein of each animal in all groups at 3-4 day-interval starting from treatment up to conception. Blood samples were centrifuged at $3000 \mathrm{rpm}$ for 10 minutes to separate blood plasma which stored at $-20^{\circ} \mathrm{C}$ for determination of progesterone ( $\mathrm{P} 4)$ concentration in blood plasma.

\section{Detection of estrus and insemination:}

At the beginning of 10 days of postpartum, an infertile bull (teaser) was introduced to cows of each group for 20 minutes three times daily at 6 a.m., 12 p.m. and 3 p.m. to detect the onset of the $1^{\text {st }}$ esturs. Estrus was recorded in cows receptive for teaser and stood for mounting by the teaser. Cows being in heat were artificially inseminated. Number and length of estrous cycles from calving up to conception were recorded. Average concentration of P4, P4 peak and interval to P4 peak during the estrous cycle were determined. Also, post-teatment $1^{\text {st }}$ ovulation, $1^{\text {st }}$ estrus and intervals post-treatment, number of services per conception (NSC), days open (DO) and conception rate (CR \%) were recorded. Conception was performed by rectal palpation on day 60 post-insemination and was indicated by P4 concentration on day 14 post-insemination in non-return cows.

\section{Progesterone assay:}

Direct radioimmunoassay technique (RIA) was performed for determination of plasma progesterone concentration using antibody-coated tubes kit (Diagnosis systems, laboratories Texas, USA) according to the procedure outlined by the manufacture. According to the manufacture's information, the radioimmunoassay of progesterone is a competition assay. Sample and standards are incubated with ${ }^{125}$ I-labeled progesterone, as tracer, in antibody-coated tubes. After incubation the content of tubes is aspirated and bound radioactivity is measured. A calibration curve is established and unknown values are calculated by interpolation from the curve. The standard curve of progesterone concentration ranged from 0 to 2.4 and 0 to $2.0 \mathrm{ng} / \mathrm{ml}$. The intra-and inter assay coefficient of variation were 5.4 and $9.1 \%$, respectively.

\section{Statistical analysis:}

The obtained data were statistically analyzed according to Snedecor and Cochran (1980) using programm of SAS (2004). The significant differences among treatment groups were tested using Duncan's Multiple Range Test (Duncan, 1955). The statistical model used was:

$Y_{i j}=U+A_{i}+e_{i j}$.

Where, $Y_{i j}=$ Observed values, $U$ = Overall mean, $A_{i}=$ Experimental group, $\mathbf{e}_{i j}=$ Random error

The level of statistical significance was set at $\mathrm{P}<0.05$.

\section{RESULTS AND DISCUSSION}

\section{Milk yield:}

Results presented in Table (2) revealed that L-tyrosine treatment significantly $(\mathrm{P}<0.05)$ increased average daily milk production during the $2^{\text {nd }}$ four months of lactation in term of actual milk yield (AMY) by 14.48 and $15.17 \%$, respectively. Whereas, it was increased based on $4 \%$ fat corrected milk yield (FCMY) by 12.59 and $17.04 \%$ in G2 and G3 cows as compared to the control one. It was interested to note that L-tyrosine treatment at day 140 postpartum (G3) significantly $(\mathrm{P}<0.05)$ increased percentages of fat, protein and lactose as compared to G1 $(3.65,3.07$ and $4.16 \%$ vs. 3.54 , 2.75 and $4.00 \%)$, respectively. However, the treatment with L-tyrosine at day 121 postpartum (G2) significantly $(\mathrm{P}<0.05)$ increased only percentages of protein and lactose by 2.98 and $4.23 \%$ as compared to G1 (Table 2). The increase obtained in AMY for cows in G2 and G3 as a results of Ltyrosine treatment reflected in a significant $(\mathrm{P}<0.05)$ increase in yields of protein, lactose and fat in treated groups than in untreated control cows (Table 2). Also, somatic cell count showed significantly $(\mathrm{P}<0.05)$ lower in G2 and G3 than in G1 based upon L-tyrosine treatment $\left(285.2\right.$ and 271.4 vs.365.6 $\times 10^{3} / \mathrm{ml}$, respectively, Table 2) indicating the beneficial effect of L-tyrosine treatment for producing clean milk. In agreement with the marked increase in milk production of cows in treated groups (G2 and G3), Abu ElHamd et al., (2010) found that L-tyrosine treatment improved $(\mathrm{P}<0.05)$ cow's daily milk production by $15.6 \%$ in compared with that of untreated control cows. In addition, L-tyrosine treated groups had a 
higher $(\mathrm{P}<0.05)$ percentages of fat and protein as compared to the control. Similarly, Rae and Ingalls (1984) found that oral administration of tyrosine to dairy cows increased milk production by 1.0 $\mathrm{kg} /$ day. However, there was no effect on FCMY yield, milk composition and milk fat yield, but yields of milk protein and lactose were increased by tyrosine supplementation. This is mostly attributed to the increase in blood supply (Mepham, 1982) and the energy intake of mammary gland cells (Anderson, 1979 and Wurtman, 1982) in addition to its effect on increasing growth hormone via its effect on brain catecholamine's (Martin, 1980) in particular norepinephrine who are believed to be potent stimulators of growth hormone $(\mathrm{GH})$ release.(Wurtman, 1982). This explanation is supported by the previous findings of Machlin (1973) and Peel et al. (1981) who found that administration of exogenous growth hormone increases milk production.

Table (2): Yield and composition of milk produced by cows in different experimental groups.

\begin{tabular}{|c|c|c|c|c|}
\hline \multirow{2}{*}{ Item } & \multicolumn{3}{|c|}{ Experimental group } & \multirow{2}{*}{$\pm \mathrm{MSE}$} \\
\hline & G1 & $\mathrm{G} 2$ & G3 & \\
\hline \multicolumn{5}{|l|}{ Average daily milk yield (kg/day): } \\
\hline Actual milk yield & $14.5^{\mathrm{b}}$ & $16.6^{\mathrm{a}}$ & $16.7^{\mathrm{a}}$ & 0.25 \\
\hline $4 \%$ fat corrected milk & $13.5^{\mathrm{b}}$ & $15.2^{\mathrm{a}}$ & $15.8^{\mathrm{a}}$ & 0.22 \\
\hline \multicolumn{5}{|l|}{ Milk composition (\%): } \\
\hline Fat & $3.54^{\mathrm{ab}}$ & $3.46^{\mathrm{b}}$ & $3.65^{\mathrm{a}}$ & 0.038 \\
\hline Protein & $2.75^{\mathrm{b}}$ & $2.98^{\mathrm{a}}$ & $3.07^{\mathrm{a}}$ & 0.045 \\
\hline Lactose & $4.0^{\mathrm{b}}$ & $4.23^{\mathrm{a}}$ & $4.16^{\mathrm{a}}$ & 0.039 \\
\hline \multicolumn{5}{|l|}{ Component yields (g/day): } \\
\hline Fat & $51.33^{\mathrm{b}}$ & $57.60^{\mathrm{ab}}$ & $60.96^{\mathrm{a}}$ & 2.94 \\
\hline Protein & $39.87^{\mathrm{b}}$ & $49.47^{\mathrm{a}}$ & $51.27^{\mathrm{a}}$ & 4.34 \\
\hline Lactose & $58.0^{\mathrm{b}}$ & $70.22^{\mathrm{a}}$ & $69.47^{\mathrm{a}}$ & 3.21 \\
\hline $\begin{array}{l}\text { Somatic cell count: } \\
\left(10^{3} / \mathrm{ml}\right)\end{array}$ & $365.6^{\mathrm{a}}$ & $285.2^{\mathrm{b}}$ & $271.4^{\mathrm{b}}$ & 21.4 \\
\hline
\end{tabular}

On the other hand, the observed increase in percentage and yield of milk protein in treated groups may attributed to an elevated supply of tyrosine to the mammary gland, whereas plasma tyrosine is the sole precursor of tyrosine in milk protein (Mepham, 1982), so an adequate supply of exogenous tyrosine is probably essential for synthesis of milk protein. The same author also, added that there is a relationship between uptake of tyrosine by the mammary gland and its transfer into milk, suggesting that the availability of tyrosine could limit milk protein synthesis under some conditions. Moreover, Guinard et al. (1994) and Metcalf et al. (1994 and 1996) showed that when supplemental protein or amino acid are administered to dairy cows, the mammary uptake of those amino acid and extract either more peptides or free amino acid to meet the net requirements for milk protein synthesis.

\section{Reproductive traits:}

It was interested to note that the cows in both treatment groups did not exhibit estrous activity prior to L-tyrosine treatment. Data in Table (3) showed that the interval from tyrosine treatment to oestrus incidence in G2 and G3 was 6.5 and 7.13 days, respectively. The early incidence of estrus in cows treated with L-tyrosine was indicated by Wetzel (1985) who detected a Graafian follicle after three days in dairy cows treated with oral intake of a single dose of L-tyrosine (100 mg/kg LBW). Also, Munsterer (1987) recorded about $90 \%$ of cows suffering from anestrus came into heat after three to four days of treatment with $50 \mathrm{~g}$ L-tyrosine per cow. The positive effect of L-tyrosine on induction of estrus in anestrus buffalo cows was indicated by El- Amrawi, et al. (1991), who found that about $87.5 \%$ of buffalo-cows came to heat within 6-9 days after treatment with a single oral dose of Ltyrosine $(100 \mathrm{mg} / \mathrm{kg}$ body weight). Also, Stevnson et al. (1997) recorded that supplemental tyrosine tended to reduce intervals to first postpartum ovulation of cows. Furthermore, El-Amrawi, et al. (1992) found that about $85 \%$ of buffalo-heifers exhibited heat within 3-4 days after treatment a single oral dose of L-tyrosine $\left(100 \mathrm{mg} / \mathrm{kg}\right.$ body weight). This means that postpartum $1^{\text {st }}$ oestrus interval (PPFEI) was 126.5 days in $\mathrm{G} 2$ being significantly $(\mathrm{P}<0.05)$ shorter by 31.5 and was 147.1 days in $\mathrm{G} 3$, being significantly $(\mathrm{P}<0.05)$ shorter by 10.9 days than that of the control group $(158.0$ days $)$. In accordance with the present results in particular for cows in G2 treated with L-tyrosine on postpartum period, 
several authors reported that exogenous tyrosine induced follicular growth and estrus in anovulatory dairy cows (Wetzel, 1985; Hammerl, 1986 and Munsterer, 1987).

Table (3): Reproductive traits of cows in different experimental groups.

\begin{tabular}{|c|c|c|c|c|}
\hline \multirow{2}{*}{ Item } & \multicolumn{3}{|c|}{ Experimental group } & \multirow{2}{*}{ MSE } \\
\hline & G1 & G2 & G3 & \\
\hline Interval from treatment to $1^{\text {st }}$ estrus (day) & - & 6.50 & 7.13 & 1.10 \\
\hline Postpartum $1^{\text {st }}$ service interval (day) & $158.0^{\mathrm{b}}$ & $126.5^{\mathrm{c}}$ & $147.1^{\mathrm{a}}$ & 1.60 \\
\hline Conception rate $1^{\text {st }}$ service $(\%)$ & 20 & 60 & 40 & \\
\hline Conception rate $2^{\text {nd }}$ service $(\%)$ & 20 & 40 & 20 & \\
\hline Conception rate $3^{\text {rd }}$ service $(\%)$ & 20 & - & 20 & \\
\hline Number of services per conception & $2.00^{\mathrm{a}}$ & $1.40^{\mathrm{b}}$ & $1.75^{\mathrm{ab}}$ & 0.10 \\
\hline Days open (day) & $172.0^{\mathrm{a}}$ & $134.0^{\mathrm{b}}$ & $158.1^{\mathrm{ab}}$ & 6.10 \\
\hline Total conception rate $(\%)$ & $60^{c}$ & $100^{\mathrm{a}}$ & $80^{\mathrm{b}}$ & \\
\hline
\end{tabular}

Moreover, Stevenson et al. (1997) found that tyrosine increased the percentage of cows in estrus. While in sow, exogenous tyrosine improved expression of estrus (Hammerl and Russe, 1987b). Inspite these findings, L-tyrosine treatment had beneficial effect on number of services per conception (NS/C) and days open (DO). L-tyrosine treatment of cows in G2 significantly $(\mathrm{P}<0.05)$ reduced NS/C to 1.4 services and DO to 134.0 days as compared to 2.0 services and DO of 172.0 days in the control group. Also, similar trend was recorded in G3 (1.75 services and 158.1 days, respectively), but the differences between G3 and the other two groups (G1 and G2) were not significant. More benefits were obtained from L-tyrosine treatment in term of conception rate $(\mathrm{CR})$, being significantly $(\mathrm{P}<0.05)$ the highest in G2 $(100 \%)$, the modest in G3 $(80 \%)$ and the lowest in G1 $(60 \%)$. Such trend was in agreement with the results of Hammerl (1986) who reported that the conception rate was greater $(69 \%)$ in anestrous dairy cows detected in estrus after tyrosine treatment than in anestrous cows detected in estrus after receiving no tyrosine. Similarly, Abu El-Hamed et al. (2010) in cows, Shamiah et al., (2013) in Frisian heifers and Ibrahim (2010) in sheep, found that animals treated with L-tyrosine administration had a higher conception rate in compared with that untreated. In addition, the amino acid tyrosine, a bloodborne metabolite, may be involved in stimulating $\mathrm{GnRH}$ release because availability of tyrosine influences synthesis of norepinephrine (Wurtman et al., 1981; Gibson and Wurtman, 1986; Acworth et al., 1988) a neurotransmitter that stimulates GnRH release (Ramirez et al., 1984; Terasawa et al., 1988). In addition, El- Amrawi, et al. (1991) found that the CR of buffalo-cows after treatment with a single oral dose of L-tyrosine (100mg/kg body weight) at day 42 post service was $67 \%$. Also, Aumann (1987) showed that after L-tyrosine administration in a dose of $100 \mathrm{mg} / \mathrm{kg}$ body weight to the bitches in their food at the $5^{\text {th }}, 6^{\text {th }}$ and the $7^{\text {th }}$ day of pro-estrus period, a higher mounting capability and pregnancy rate were observed in treated animals than in control one.

\section{Ovarian activity:}

Results in Table (4) showed that L-tyrosine treatment in G2 and G3 significantly $(\mathrm{P}<0.05)$ decreased the average number of estrus cases and ovulatory cycles per cow, and P4 concentration during the ovulatory cycles in compared with those of control group. The decrease in no. of cycles may be due to increase in the milk yield as a result of elevation in prolactin level which suppress FSH release from anterior pituitary gland. The present results also showed that P4 level significantly $(\mathrm{P}<0.05)$ increased prior to estrus incidence in $\mathrm{G} 2$ and G3 as compared to G1. On the other hand, the differences in average number of total ovulations, silent ovulations per cow, ovulatory cycle length as well as $\mathrm{P} 4$ peak and interval to $\mathrm{P} 4$ peak during the ovulatory cycles among experimental groups were not significant. The decreased average number of estrus per cow was associated with that exogenous tyrosine induced follicular growth and ovulation in anovulatory dairy cows (Wetzel, 1985; Hammerl, 1986; Munsterer, 1987, Abu El-Hamd et al. 2010 and Abu El-Hamd, 2013). The marked elevation in P4 concentration during the interval from treatment to estrus incidence in G2 and G3 than in G1 was in agreement with several authors. In this respect, El-Amrawi et al. (1991) found that P4 level in anestrous buffalo pre-treatment was lower than $0.2 \mathrm{ng} / \mathrm{ml}$ whereas, a higher values for P4 $(1.7 \mathrm{ng} / \mathrm{ml})$ were estimated in animals treated with L-tyrosine $(100 \mathrm{mg} / \mathrm{kg}$ body weight) than that recorded in the control one (0.16 ng/ml). Also, Abu El-Hamd (2013) and Shamiah et al., (2013) found that, one oral dose of L-tyrosine induced a significant increase in P4 concentration compared to the control. 
The increased level of P4 may be due to the stimulatory effect of tyrosine on GnRH. L-tyrosine may involve stimulation of GnRH release because availability of tyrosine influences synthesis of norepenephrine (Wurtman et al., 1981), a neurotransmitter that stimulates hypothalamic GnRH release and pulsatile and pre-ovulatory release of LH from pituitary gland (Ramiez et al., 1984 and Terasawa et al., 1988). Moreover, the catecholamines may mediate effects of other neurotransmitters and gonadal steroids on release of GnRH (Ramirez et al., 1984 and Yen and Vale, 1990).

Table (4): Ovarian activity and progesterone (P4) concentration of cows in different groups starting from treatment up to conception.

\begin{tabular}{|c|c|c|c|c|}
\hline \multirow{2}{*}{ Item } & \multicolumn{3}{|c|}{ Experimental group } & \multirow{2}{*}{ MSE } \\
\hline & G1 & $\mathrm{G} 2$ & G3 & \\
\hline Total number of ovulations/cow & 3.50 & 2.75 & 3.00 & 0.33 \\
\hline Number of silent ovulations/cow & 0.75 & 0.00 & 1.00 & 0.26 \\
\hline Total number of estrus cases & $3.25^{\mathrm{a}}$ & $2.50^{\mathrm{b}}$ & $2.25^{\mathrm{b}}$ & 0.19 \\
\hline Number of ovulatory cycles/cow & $3.25^{\mathrm{a}}$ & $2.25^{\mathrm{b}}$ & $2.50^{\mathrm{b}}$ & 0.14 \\
\hline Ovulatory cycle length (day) & 20.64 & 21.25 & 22.67 & 3.41 \\
\hline Average of $\mathrm{P} 4$ prior to estrus activity ${ }^{1}$ & $0.214^{\mathrm{b}}$ & $0.435^{\mathrm{a}}$ & $0.417^{\mathrm{a}}$ & 0.03 \\
\hline Average $\mathrm{P} 4$ concentration $(\mathrm{ng} / \mathrm{ml})^{2}$ & $2.601^{\mathrm{a}}$ & $1.841^{\mathrm{b}}$ & $1.739^{\mathrm{b}}$ & 0.21 \\
\hline $\mathrm{P} 4$ peak $(\mathrm{ng} / \mathrm{ml})^{2}$ & 7.190 & 6.221 & 5.701 & 0.74 \\
\hline Interval to $\mathrm{P} 4$ peak (day) ${ }^{3}$ & 10.14 & 11.63 & 11.56 & 2.64 \\
\hline
\end{tabular}

${ }^{1}$ From time of treatment to estrus incidence.

${ }^{2}$ During the ovulatory cycles.

${ }^{3}$ From the beginning of the ovulatory cycle.

In conclusion: Upon the results obtained and mentioned above, L-tyrosine is very useful and could be used for treating cows after calving for overcoming reproductive problems associated with ovarian activity and some reproductive traits such as incidence of estrus, interval from calving to the first estrus, postpartum first service, days open, number of services per conception to improve conception rate, and finally improve cow's reproductive performance, milk yield and its composition.

\section{REFERENCES}

A.O.A.C. (2000). Association of Official Analytical Chemists. Official Methods of Analysis, $17^{\text {th }}$ Ed., Washington, DC.

Abu El-Hamd, M.A., Sh. A. Gabr and M.S. Sayah (2010). Effect of L-tyrosine during early postpartum periods on milk yield and reproductive performance of Friesian cows. J. Animal and Poultry Production, Mansoura Univ., Vol. 1 (5): 187 - 193.

Abu El-Hamd, M.A. (2013). The onset of puberty, hormones and blood metabolites in Friesian heifers treated with L-tyrosine. Proceeding of the $4^{\text {th }}$ scientific conference of Animal Production Research Institute, Cairo, Egypt, 12-13 November, 93-105.

Abu El-Hamd, M.A. and M.S. Sayah (2015). Effect of L-tyrosine on growth performance, age of sexual puberty, semen quality and testosterone level in Friesian bulls. Egyptian J. Anim. Prod., 52 (1):13-37.

Acworth, I. N., M. J. During, and R. J. Wurtman (1988). Tyrosine: Effects on catecholamine release. Brain Res. Bull., 21:473-477.

Anderson, G. H. (1979). Control of protein and energy intake: role of plasma amino acids and brain neurotransmitters. Can. J. Physiol. Pharmacol., 57:1043.

Aumann, J. (1987): Beitrag zur behandlung von fertilitatsstorungen der deutschen schaferhudin. Diss. Mid. Vet., Munchen.

Duncan, D. B. (1955). Multiple rang and multiple F test. Biometrics, 11: 1-42. 
El-Amrawi, G. A.; A.D. Zakaria and M.T. Nasr (1991): L-tyrosine and ovarian activity in Egyptian buffaloes. Assiut. Vet. Med. J., 25: 211-216.

El-Amrawi, G. A.; F.M. Hussein; Iman, E. El-Bawab and A.D. Zakaria (1992): The induction of puberty in delayed pubertal buffalo-heifersby L-tyrosine. Cairo International Meeting on Working Animals, 13-16 April, National Research Center.

El-Amrawi, G.A. (2008). Effect of Theriogon in concentration of testosterone in buffalo-bulls. 16th International Congress on Animal Reproduction (ICAR) 12-16 Juli Budapest, Hungura.

Gabr, Sh. A. (2009). The relay of sexual puberty in rabbit male by L-tyrosine or carnitine treatment. J. Agric. Res. Kafrelsheikh Univ., 35 (1) 56-68.

Gibson, C. J., and R. J. Wurtman. (1986). Physiological control of brain norepinephrine synthesis by brain tyrosine concentrations. Life Sci., 22: 1399-1406.

Guinard, J., H. Rulquin, and R. Verite (1994). Effect of graded levels of duodenal infusions of casein on mammary uptake in lactating cows. 1. Major nutrients. J. Dairy Sci., 77: 2221-2231.

Hall, J. B., K. K. Schillo, S. M. Hileman, and J. A. Boling (1992). Does tyrosine act as a nutritional signal mediating the effects of increased feed intake on luteinizing hormone patterns in growthrestricted lambs? Biol. Reprod., 46: 573-579.

Hammerl, J. (1986). Der Einfluß der Aminosa“ure L-Tyrosin, als ein Katecholamin-Vorla“ufer, auf die Reproduktion bei Ku“hen. In: Proc. 14th World Cong. on Diseases of Cattle, Vol 2: 911. Dublin, U.K.

Hammerl, J. and M. Russe. (1987a). Der Einfluß der Aminosa“uren L-tyrosin und L-tryptophan auf das Fruchtbarkeitsgeschehen bei jungen Ratten. Zuchthygiene (Berl.), 22: 80-84.

Hammerl, J. and M. Russe (1987b). Reproduktionssteigerung bei Sauen durch perorale Verabreichung von L-Tyrosin. Tieraerztl. Umsch., 42: 551-554.

Ibrahim, M.Y.M. (2010). Some studies on improving productive and reproductive performance of local sheep. Ph.D. Fac. Agric Minia Univ., Egypt.

Machlin, L.J. (1973). Effect of growth hormone on milk production and feed utilization in dairy cows. J. Dairy Sci., 56: 575.

Martin, J.B. (1980). Functions of central nervous system neurotransmitters in regulation of growth hormone secretion. Fed. Proc., 39: 2902.

Mepham, T. B. (1982). Amino acid utilization by lactating mammary gland. J. Dairy Sci., 65:287.

Metcalf, J.A., D.E. Beever, J.D. Sutton, D. Wray-Cahen, R. T. Evans, D.J. Humphries, F.R.C. Backwell, B.J. Bequette, and J.C. MacRae (1994). The effect of supplementary protein on in vivo metabolism of the mammary gland in lactating dairy cows. J. Dairy Sci., 77: 1816-1827.

Kim, S.W., R.D. Mateo, Y.L. Yin and G. Wu (2007). Functional amino acids and fatty acids for enhancing production performance of sows and Piglets. Asian-Aust. J. Anim. Sci., Vol. 20 (2): 295-306.

Metcalf, J. A., D. Wray-Cahen, E. E. Chettle, J. D. Sutton, D. E. Beever, L. A. Crompton, J. C. MacRae, B. J. Bequette, and F.R.C. Backwell (1996). The effect of dietary crude protein as protected soybean meal on mammary metabolism in the lactating dairy cow. J. Dairy Sci., 79: 603611.

Munsterer, P. (1987). Zur Anwendung der Aminosaure L-Tyrosin in der Sterilita“tsbehandlung des Milchrindes. Vet. Dissertation. Univ. of Munich, Germany.

NRC, (2001). Nutrient requirements of Dairy cattle. $7^{\text {th }}$ rev. ed. National Research Council. National Academic Press, Washington DC.

Peel, C.J., D.E. Bauman, R.C. Gorewit, and C. J. Sniffen (1981). Effect of exogenous growth hormone on lactational performance in yielding dairy cows. J. Nutr., 111:1662.

Rae R.C. and J.R. Ingalls (1984). Lactational response of dairy cow to oral administration of Ltyrosine. J. Dairy Sci., 68: 1430-1438. 
Ramirez, V.D., H.H. Feder, and C.H. Sawyer (1984). The role of brain catecholamines in the regulation of LH secretion: A critical inquiry. In: L. Martini and W. F. Ganong (Ed.) Frontiers in Neuroendocrinology, Vol. 8: 27. Raven Press, New York.

SAS. (2004). SAS/STAT User's Guide: Volumes 1-7. SAS Institute Inc., Cary, North Carolina.

Shamiah, Sh.M.; M.A. Abu El-Hamd; Sh.A. Gabr and M.S. Sayah (2013). Growth, blood parameters and reproductive performance in Friesian heifers treated with L-tyrosine. Proceeding of the 4th scientific conference of Animal Production Research Institute, Cairo, Egypt, 12-13 November, p. 73-83.

Snedecor, G. W. and W. G. Cochran (1980). Statistical methods., $7^{\text {th }}$ Ed. Allied Pacific, Bomobay.

Stevenson, J.S.; J.R. Jaeger; I. Rettmer; M.W. Smith and L.R. Corah (1997). Luteinizing hormone release and reproductive traits in anestrous, estrus-cycling, and ovariectomized cattle after tyrosine supplementation. J. Anim. Sci., 75 (10): 2754-2761.

Terasawa, E., C. Krook, D.L. Hei, M. Gearing, N.J. Schultz, and G.A. Davis (1988). Norepinephrine is a possible neurotransmitter stimulating pulsatile release of luteinizing hormone releasing hormone in the rhesus monkey. Endocrinology, 123: 1808-1816.

Wetzel, G. (1985). Der Einfluß der Aminosa ure L-Tyrosin auf das Fruchtbarkeitsgeschehen beim Rind. Vet. Dissertation. Univ. of Munich, Germany.

Wurtman, R.J. (1982). Nutrients that modify brain function. Am. Sci., 246: 50-59.

Wurtman, R.J. (1986). Effects of their nutrient precursor on the synthesis and release of serotonin, the catecholamines and acetylcholine-Implications for behavioral disorders. Clin. Neuropharmacol., 9: 506.

Wurtman, R.J., F. Hefti, and E. Melamed (1981). Precursor control of neurotransmitter synthesis. Pharmacol. Rev., 32: 315-335.

Yen, S.S.C. and W.V. Vale (Ed.) (1990). Neuroendocrine regulation of reproduction. In: Proc. Symp. Neuroendocrine Regulation of Reproduction, November 5-9, Napa, CA, Serono Symposia, USA, Nonvell.
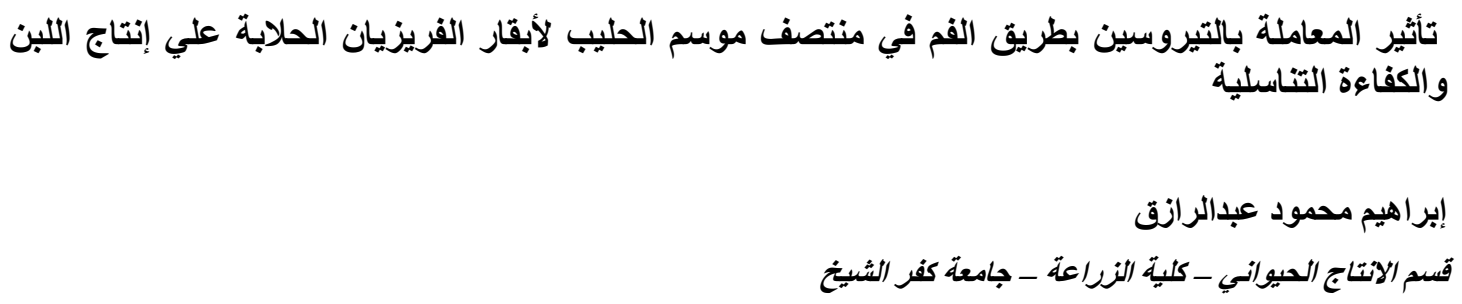

\footnotetext{
تم تقسيم 30 بقرة فريزيان حلابة عمر ها من 31-59 شهر ومتوسط وزن الجسم الحي 502.6 كجم إلي ثلاثة مجمو عات متشابهة

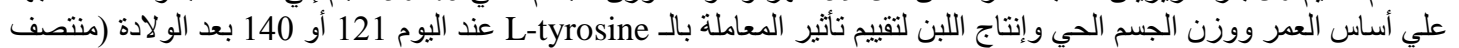

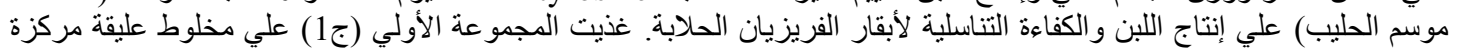

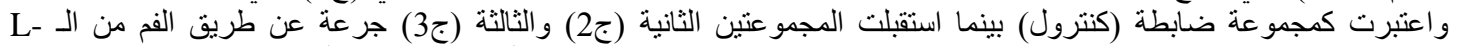

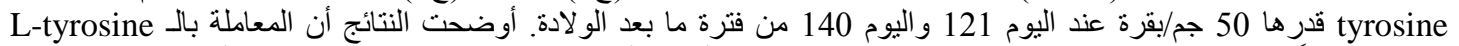
حسنت معنوياً (P)

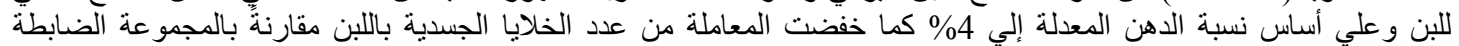

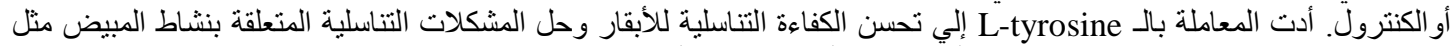

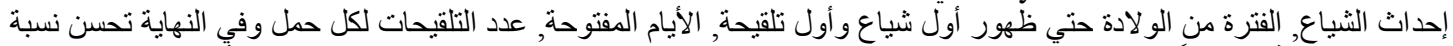

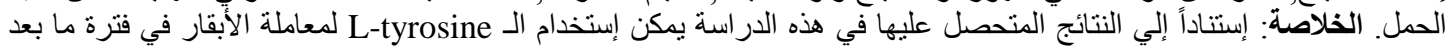

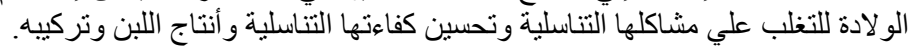

